\title{
Honoring the Life and Work of Renée Claire Fox
}

\author{
Atwood D. Gaines
}

Published online: 30 October 2013

(C) Springer Science+Business Media New York 2013

In the first number of the present volume of Culture, Medicine and Psychiatry 37(1):1, we noted that, in 2013, CMP would celebrate the life and work of noted medical sociologist/bioethicist, Renée Claire Fox. Her discipline crossing and synthesizing is here summarized to honor her and to encourage readers not familiar with her work to consider it seriously. It is a wide-ranging body of work that has something for every reader of CMP. Below is some biographical information. This is followed by a summary of her books after which follows a representative list of her publications in journals and books.

\section{Renée Claire Fox}

Renée Claire Fox is now Professor Emerita of Sociology and Annenberg Professor Emerita of the Social Sciences at the University of Pennsylvania. She earned her Bachelors degree from Smith College (1949) and her $\mathrm{PhD}$ in Sociology at Radcliffe College, Harvard University, in 1954 where she studied in the Department of Social Relations. Before going to the University of Pennsylvania in 1969, Dr. Fox was a member of the Columbia University Bureau of Applied Social Research and lectured for more than a decade at Barnard, and she served as a Visiting Lecturer in the Department of Social Relations at Harvard.

At the University of Pennsylvania, she was a professor in the Department of Sociology and held secondary appointments in the Departments of Psychiatry and Medicine and in the School of Nursing. She was also named the Annenberg

\footnotetext{
A. D. Gaines $(\bowtie)$

Departments of Anthropology, Bioethics and Psychiatry, Case Western Reserve University, Cleveland, OH, USA

e-mail: atwood.gaines@case.edu
} 
Professor of the Social Sciences, a nod to her interdisciplinary perspective. Dr. Fox served as the Chair of the Department of Sociology from 1972 to 1978 , one of the very first women to do so in an Ivy League university. In 1998, she retired, becoming Professor Emerita of Sociology, and the Annenberg Professor Emerita of the Social Sciences, and also Emerita Senior Fellow of the Center for Bioethics.

Dr. Fox has developed a number of key research areas that well mirror her interdisciplinary bent. She is preeminently a sociologist of medicine but with a difference. She conducted participant observation of medical work in Belgium, producing her first book, Experiment Perilous. This work not only considered medical practice but also medical research, patient experiences and the nature of uncertainty for patients and healers. Out of this work grew her interests in medical education as well as medical ethics, a field she engaged some years before there was such a thing as Bioethics. She would later be the co-founder of what became the Hastings Center as well as medical sociology.

Her later work on medicine (now biomedicine) continued to pay attention to the nature of uncertainty in medical theory and practice as in Courage to Fail (with medical historian Judith Swazey) and to the new medical technologies including organ transplantation and dialysis. Her research and commentaries on bioethics always have been critical of its lack of concern for individuals and social and cultural context. She has argued, rightly, that bioethicists should be trained in the social sciences before being trained in bioethics.

As an ethnographic researcher, though a sociologist, Dr. Fox has conducted such fieldwork in Europe, particularly Belgium, but also Russia (her parents place of origin), the Democratic Republic of the Congo, and in China and the United States. Her comparative, ethnographic method was often wedded to historical analysis as with the development of the medical profession in the Congo and history of the people and institutions of Belgium over the first half of the twentieth century $(1968,1994)$.

Her service to the disciplines in which she has worked include serving as associate editor of the Journal of Health and Social Behavior from 1985 to 1987 and the Editorial Board of the Journal of the American Medical Association (19811994) and Technology in Society, Human Medicine and The American Scholar.

Some of Dr. Fox's memberships and honors include:

- Member of the American Academy of Arts and Sciences

- Member of the American Philosophical Society

- Member of the Institute of Medicine of the National Academy of Sciences

- Fellow of the American Association for the Advancement of Science

- Honorary Member of Alpha Omega Alpha Medical Honor Society

In addition to these memberships and honors, Dr. Fox holds two medals of Honor, a Radcliffe Graduate School Medal, and a Centennial Medal from the Graduate School of Arts and Sciences at Harvard University. Dr. Fox has received several teaching awards and has been awarded some eleven honorary degrees. She is a recipient of the Leo G. Reeder Award Distinguished Contributions to Medical Sociology given by the American Sociological Association. In 1995, she had bestowed upon her the Chevalier de l'Ordre de Leopold le II $^{\mathrm{eme}}$ (knighthood) by the 
Belgium Government. And, more recently, in 2007, Dr. Fox received the Lifetime Achievement Award from the American Society for Bioethics and Humanities (ASBH).

\section{Selected Articles of Renée Claire Fox}

(In Chronological Order)

The following citations, in their chronological order, not that of the secondary authors, clearly shows the key areas of Dr. Fox's research. The list is illustrative rather than exhaustive and it, with the next section on her book length works, is meant to encourage exploration rather than provide exhaustive analyses thereof. Fox, Renée C.

1957 Training for Uncertainty. In The Student-Physician: Introductory Studies in the Sociology of Medical Education. Merton, Robert K., George Reader and Patricia Kendall, Editors. Cambridge, MA: Harvard University Press. pp. 207241.

Fox, Renée C.

1960 Some Social and Cultural Factors in American Society Conducive to Medical Research on Human Subjects. Clinical Pharmacology and Therapeutics 1:423-443.

Fox, Renée C.

1962 Medical Scientists in a Château. Science 136:476-483.

Fox, Renée C. and Harold I. Leif

1963 Training for 'Detached Concern' in Medical Students. In The Psychological Basis of Medical Practice. Victor Harold and Nina Leif, Editors. New York, NY: Harper and Row. pp. 12-35.

Fox, Renée C.

1964 An American Sociologist in the Land of Belgian Medical Research. In Sociologists at Work. Phillip E. Hammond, Editor. New York, NY: Basic Books. pp. 345-391.

Fox, Renée C.

1970 A Sociological Perspective on Organ Transplantation and Hemodialysis. Annals of the Academy of Sciences 169(2):406-429.

Fox, Renée C.

1974 Ethical and Existential Developments in Contemporaneous American Medicine. Milbank Memorial Fund Quarterly 52:445-483. 
de Craemer, W, J. Vansina, and Renée C. Fox

1976 Religious Movements in Central Africa. Comparative Studies in Society and History 18(4):458-475.

Fox, Renée C.

1977 The Medicalization and Demedicalization of American Society. Daedalus 106(1):9-22.

Fox, Renée C.

1977 The Sociology of Modern Medical Research. In Asian Medical Systems. Charles Leslie, Editor: Berkeley, CA: University of California Press.

Fox, Renée C.

1978 Why Belgium? European Journal of Sociology 19(2).

Fox, Renée C.

1979 The Autopsy: Its Place in the Attitude-Learning of Second Year Medical Students. In Essays in Medical Sociology. Renée C. Fox. New York: Wiley. pp. 51-77.

Fox, Renée C.

1981 The Sting of Death in American Society. Social Service Review 55(1):4259.

Fox, Renée C.

1982 Is Religion Important in Belgium? European Journal of Sociology 23(1):338.

Fox, Renée C.

1983 Exclusion from Dialysis: A Sociologic and Legal Perspective. Kidney International 19(5):739-751.

Fox, Renée C. and David Willis

1983 Personhood, Medicine and American Society. The Milbank Memorial Fund Quarterly/Health and Society 61:127-147.

Blumberg, BS and Reneé C. Fox

1985 The Daedalus Effect: Changes in Ethical Questions Relating to Hepatitis B Virus. Annals of Internal Medicine 102(3):390-394.

Fox, Renée C. and Judith Swazey

1985 Medical Morality Is Not Bioethics: Medical Ethics in China and the United States. Perspectives in Biology and Medicine 27(4):336-360. 
Anderson, Robert E, Renée Fox and Rolla Hill

1990 Medical Uncertainty and the Autopsy: Occult Benefits for Students. Human Pathology 21(2):128-135.

Fox, Renée C.

1990 The Evolution of American Bioethics: A Sociological Perspective. In Social Science Perspectives on Medical Ethics. George Weiss, Editor. Dordrecht, the Netherlands. Kluwer Academic Publishers. pp. 201-220.

Fox, Renée C.

1995 Medical Humanitarianism and Human Rights: Reflections on Doctors Without Borders and Doctors of the World. Social Science \& Medicine 41(12):1607-1626.

Fox, Renée C.

1996 Experiment Perilous: Forty-Five Years as a Participant Observer of PatientOriented Clinical Research. Perspectives in Biology and Medicine 39(2):206-226.

Fox, Renée C.

1999 Is Medical Education Asking Too Much of Bioethics? Daedalus 128(4):1-25.

Fox, Renée C.

2000 Medical Uncertainty Revisited. In The Handbook of Social Studies in Health and Medicine. Gary L. Albrecht, Ray Fitzpatrick and Susan Scrimshaw, Editors. London, UK: Sage Publications. pp. 409-427.

Fox, Renée C.

2004 Observations and Reflections of a Perpetual Fieldworker. Annals of the American Academy of Political and Social Science 595(1):309-326.

Fox, Renée C. and Judith Swazey

2005 Examining American Bioethics: Its Problems and Prospects. Cambridge Quarterly of Healthcare Ethics 14(4).

Fox, Renée C.

2005 Cultural Competence and the Culture of Medicine. New England Journal of Medicine 353(13):1316-1319.

Fox, Renée C. and Eric Goemaere

2006 They Call It "Patient Selection” in Khayelitsha: the Experience of Médecins Sans Frontières-South Africa in Enrolling Patients to Receive Antiretroviral Treatment for HIV/AIDS. Cambridge Quarterly of Healthcare Ethics 15(3). 
Fox, Renée C., Victor Lidz, Helen Sheehan, Barrett Brenton, Heike Thiel de Bocanegra

2009 Heroic Action and Its Discontents: Safe Horizon's Response to 9/11. Society 46(4):308-318.

Fox, René C.

2010 Ignoring the Social and Cultural Context of Bioethics is Unacceptable. (Guest Editorial). Cambridge Quarterly of Healthcare Ethics 19(3):278-281.

\section{Books of Renée Claire Fox}

In Dr. Fox's first book, Experiment Perilous (1959), she shows the sort of interdisciplinarity, or rather synthesis of perspectives and methods, that CMP advocates and that the present issue highlights. In this book, Dr. Fox gives us an ethnographic study of patients and physician/researchers involved with cancer therapies with unknown efficacy. Patients and healers act in an ambiguous context without medical certainty, a topic to which she returns with Judith Swazey, a medical historian, in their Courage to Fail (1974) as noted above. Experiment Perilous was not only an early foray into what came to be called the Ethnology of Biomedicine (Gaines 1992, Ethnopsychiatry), as her study took place in Belgium, it was also a study in the field of bioethics, but with a difference; it was an ethnographic study of ethics. And, we note that the terms 'bioethics' and 'biomedical ethics' did not appear until 1971, after the publication of Van Rensselaer Potter's/(b. 1911, d. 2001) book, Bioethics: A Bridge to the Future in which the term was coined but concerned a synthesis of ecology, conservation, land ethics and human values, not biomedicine. Potter later developed the term Global Bioethics in a 1988 book of that title because biomedicine had appropriated his original term.

Developing a comparative basis for her work, much as an anthropologist would, Dr. Fox went on to combine ethnography with history in her study (with DeCraemer) of the development of the Congolese medical profession (1968). Recently, teaming again with medical historian Swazey, Fox produced their newest volume, Observing Bioethics (2006) that emphasizes observation, rather than armchair speculation, on ethics and ethical problems in medicine, as is often the case.

Combining narrative, case studies, sociological analysis and history, Fox with Judith Swazey has deeply considered the paradoxes, problems and ethical issues of organ transplantation and dialysis in the US $(1974,1992)$ and also with other ethicists (Youngner, Fox and O'Connell 1996). Showing herself to be quite the polymath, Dr. Fox published In the Belgian Chateau (1994), an historical, social and political study of identity and change in the various institutions (i.e., chateaux) of Belgium over the previous half-century. Most recently, she has given us an autobiography (2011), which chronicles her life and work and her own illnesses (polio, breast cancer), each illuminated by the local contexts and showing the narrative style seen in her earlier works. 
Dr. Fox's synthesis of ethnography, history, narrative, biography, the sociology of education, comparative research, humanitarianism, advocacy and bioethics is, of course, good reason to honor her in the pages of Culture, Medicine and Psychiatry the editorial ethos of which advances a synthesis of the enterprises of meaning from the humanities and social sciences. It is in this spirit of synthesis that we honor Dr. Renée Fox and her work.

\section{Books of Renée Claire Fox}

Fox, Renée Claire

1959 Experiment Perilous: Physicians and Patients Facing the Unknown. New York: the Free Press.

1979 Essays in Medical Sociology: Journeys into the Field. New York, NY: Wiley.

1989 The Sociology of Medicine. Upper Saddle River, NJ. Prentice-Hall.

1994 In the Belgian Chateau: the Spirit and Culture of a European Society in an Age of Change. Chicago: Ivan R. Dee Publisher.

2011 In the Field: A Sociologist's Journey. New Brunswick, NJ: Transaction Publishers.

\section{Books of Renée Claire Fox with Others}

DeCraemer, Willy and Renée Claire Fox

1968 The Emerging Physician: a Sociological Approach to the Development of a Congolese Medical Profession. Stanford, CA: Hoover Institute, Stanford University Press.

Fox, Renée Claire and Judith Swazey

1974 The Courage to Fail: A Social View of Organ Transplants and Dialysis. Chicago, IL: University of Chicago Press.

Fox, Renée Claire and Judith Swazey

1992 Spare Parts: Organ Replacement in American Society. Oxford, UK: University of Oxford Press.

Youngner, Stuart J, Renée Claire Fox, Laurence J. O’Connell, editors

1996 Organ Transplantation: Meanings and Realities. Madison, WI: University of Wisconsin Press.

Fox, Renée C. and Judith Swazey

2008 Observing Bioethics. Oxford, UK: Oxford University Press. 